\section{FRI0306 IDIOPATHIC INFLAMMATORY MYOPATHIESAND ANTISYNTHETASE SYNDROME: CONTRIBUTION OF ANTISYNTHETASE ANTIBODIES TO IMPROVE CURRENT CLASSIFICATION CRITERIA}

Martín Greco ${ }^{1}$, María Jesús García de Yébenes ${ }^{2}$, Inmaculada Alarcón ${ }^{1}$, Anahy Brandy-Garcia ${ }^{3,4}$, Iñigo Rua-Figueroa ${ }^{1}$, Estíbaliz Loza ${ }^{5}$, Loreto Carmona ${ }^{5}$. ${ }^{1}$ Hospital Universitario de Gran Canaria Dr. Negrín., Las Palmas, Spain; ${ }^{2}$ Instituto de Salud Musculoesquelética, Madris, Spain; ${ }^{3}$ Hospital Universitari Germans Trias i Pujol, Barcelona, Spain; ${ }^{4}$ Hospital Universitario Central de Asturias, Oviedo, Spain; ${ }^{5}$ Instituto de Salud Musculoesquelética, Madrid, Spain

Background: The presence of muscle weakness and anti-Jo1 anti-aminoacyl transfer RNA synthetase (ARS) autoantibodies, are evaluated in the new EULAR/ACR proposed classification criteria for adult and juvenile idiopathic inflammatory myopathies (IIM), as well as in the Solomon proposed criteria for antisynthetase syndrome (ASSD) diagnosis $(1,2)$. That favors an overlapping in both criteria fulfillment; however, the ASSD are not considered among the IIM subgroups classification. Anti-Jo1 ARS positivity is the highest weighted criterion in the EULAR/ACR criteria; nevertheless, other ARS were not included. Any ARS positivity is considered in Solomon's criteria.

Objectives: To evaluate if the detection of non-anti-Jo1 ARS could improve the EULAR/ACR criteria performance, and additionally to contribute to a better classification of the antisynthetase syndromes.

Methods: We performed an observational retrospective study in 2 centers. All patients with clinical suspicion of ASSD or myositis, and positive ARS in the myositis immunoblot (Euroimmun assay) were included. We assessed: 1) The rate of patients meeting EULAR/ACR and Solomon's criteria; 2) The rate of patients with anti-Jo1 and with non-anti-Jo1 ARS that fulfilled them; and 3) The rate of patients with non-anti-J01 ARS meeting the EULAR/ACR criteria if we assign to these antibodies the same weight as anti-Jo1 ARS.

Results: A total of 37 patients were included; $70.3 \%$ woman, with a mean age at the moment of the ARS detection of $51.4(\mathrm{SD} \pm 14.0)$ years. The frequency of ARS was: anti-Jo1 $(n=17)$, anti-PL-12 ( $n=8)$, anti-PL-7 $(n=4)$, anti-EJ $(n=4)$, and anti-OJ $(n=4)$.

Twenty-two of 34 patients (59.5\%) met EULAR/ACR criteria and 17 $(45.9 \%)$ met Solomon's criteria. Thirteen patients $(35.1 \%)$ fulfilled both criteria, representing the $59.1 \%$ of those who met EULAR/ACR criteria and the $76.5 \%$ of those who met Solomon's criteria.

Analyzing by antibodies, all patients with anti-Jo1 ARS $(n=17)$ met EULAR/ACR criteria. Among the patients with non-anti-Jo1 ARS $(n=20)$, only $5(25 \%)$ met the criteria; however, if we gave the anti-Jo1 weight to the other ARS when applying the EULAR/ACR criteria, 19 of the 20 cases $(95 \%)$ would meet them.

Besides, considering the clinical features, 10 of the 20 patients with nonanti-J01 ARS (50\%) presented clinically objectified muscle weakness, and only 4 of them met EULAR/ACR criteria; nevertheless, weighing any ARS as anti-J01, the other 6 cases would be reclassified as IIM.

Conclusion: All cases with anti-Jo1 positivity met EULAR/ACR criteria, but not those with other ARS. Nevertheless, when we applied the EULAR/ACR criteria assigning to all ARS the same weight as anti-Jo1, all except one patient fulfilled the criteria; thus, the most important result was that all patients with clinically objectified muscle weakness and nonanti-Jo1 ARS that initially did not meet the EULAR/ACR criteria could be re-classified as IIM.

In this way, our results suggests that the detection of non-anti-Jo1 ARS in patients with myopathy suspicion, could increase the sensitivity of the EULAR/ACR classification criteria; and that the ASSD, when presents myositis, should be considered among the IIM classification subgroups.

\section{REFERENCES:}

[1] Lundberg IE, et al. Annals of the rheumatic diseases. 2017;76(12):195564.

[2] Solomon J, et al. Jornal brasileiro de pneumologia. 2011;37(1):100-9.

Disclosure of Interests: Martín Greco: None declared, María Jesús García de Yébenes: None declared, Inmaculada Alarcón: None declared, Anahy Brandy-Garcia: None declared, Iñigo Rua-Figueroa: None declared, Estíbaliz Loza Grant/research support from: Roche, MSD, Pfizer, Abbvie, BMS, UCB, Actelion, Celgene, Grunenthal and Sanofi, Loreto Carmona Grant/ research support from: Abbvie, Actelion, Astellas, BMS, Eisay, Gebro Pharma, Grünenthal, Leo Pharma, Lilly, MSD, Novartis, Pfizer, Roche, Sanofi-Aventis and UCB Pharma, Paid instructor for: Novartis

DOI: 10.1136/annrheumdis-2019-eular.5460

\section{FRI0307 \\ LENABASUM, A CANNABINOID TYPE 2 RECEPTOR AGONIST, REDUCES CD4 CELL POPULATIONS AND DOWNREGULATES TYPE 1 AND 2 INTERFERON ACTIVITIES IN LESIONAL DERMATOMYOSITIS SKIN}

Kristen Chen ${ }^{1,2}$, Majid Zeidi ${ }^{1,2}$, Nithin Reddy $^{1,2}$, Barbara White ${ }^{3}$, Victoria Werth ${ }^{1,2}$ ${ }^{1}$ Corporal Michael J. Crescenz VAMC, Philadelphia, United States of America; ${ }^{2}$ University of Pennsylvania, Perelman School of Medicine, Department of Dermatology, Philadelphia, United States of America; ${ }^{3}$ Corbus Pharmaceuticals, Inc., Norwood, United States of America

Background: Lenabasum is a synthetic, non-immunosuppressive, selective cannabinoid receptor type 2 (CB2) agonist that activates resolution of innate immune responses. CB2 is a G-protein coupled receptor found primarily on activated immune cells. In vitro, it has shown to affect T-cell activity, alter Th1 and Th2 cytokine production, and decrease type 1 interferon activity.

Objectives: We sought to characterize the in vivo effect of lenabasum on inflammatory cells and cytokines thought to be involved in the itch and disease pathogenesis of dermatomyositis (DM).

Methods: 22 adult patients with refractory, skin-predominant DM on stable standard-of-care treatments were recruited for a double-blind, placebo-controlled, randomized trial. Treatment was initially administered orally at a dose of $20 \mathrm{mg}$ a day for 4 weeks, and subsequently raised to $20 \mathrm{mg}$ twice a day for an additional 8 weeks. In a subset of subjects, lesional skin biopsies were collected at baseline and at Week 12. Tissues were stained via immunohistochemistry for IFN-beta, IFN-gamma, IL-4, IL-13, IL-33, IL-31, IL-31 RA, CB2 receptor, PPAR-gamma, CD4, CD8, CD69, CD11c, and mast cells. RT-PCR for IFN-beta, IFN-gamma, IL-31, IL-4 STAT6, and ST2 was performed on tissue RNA. Protein expression was quantified either by percent area positive or cells per HPF in the dermis. Statistical analyses were performed using the Wilcoxon signed-rank test. Results: CD4 expression in the skin biopsies from lenabasum-treated subjects significantly decreased at Week 12 compared to the placebo group $(p<0.05)$. There were significant reductions in IFN-beta mRNA and protein, as well as IFN-gamma mRNA and protein at Week 12 in subjects on lenabasum compared to placebo $(p<0.05)$. IL-31 protein $(p<0.01)$ was reduced at Week 12 in subjects who received lenabasum, but IL-31RA protein did not change. CB2 protein decreased significantly in the lenabasum group compared to placebo. There were no changes in IL-4, IL-13, IL-33, and PPAR-gamma protein, or the number of CD8, CD69, CD11c, or mast cells in either group. There was no significant difference in IL31, IL-4, STAT6, or ST2 mRNA expression.

Conclusion: Lenabasum reduces Type 1 and 2 interferon levels as well as T-helper cell inflammation in subjects with DM. These effects have the potential to inhibit underlying disease pathways in DM, thus contributing to clinical improvement.

\section{REFERENCES:}

[1] Kim, H.J., Zeidi, M., Bonciani, D., Pena, S.M., Tiao, J., Sahu, S. and Werth, V.P. Itch in dermatomyositis: the role of increased skin interleukin31. British Journal of Dermatology. 2018;179(3):669-678.

[2] Robinson ES, Alves P, Bashir MM, Zeidi M, Feng R, Werth VP. Cannabinoid Reduces Inflammatory Cytokines, Tumor Necrosis Factor- $\alpha$, and Type I Interferons in Dermatomyositis In Vitro. J Invest Dermatol. 2017;137 (11):2445

[3] Wong D, Kea B, Pesich R, Higgs BW, Zhu W, Brown P, et al. Interferon and biologic signatures in dermatomyositis skin: specificity and heterogeneity across diseases. PLoS One. 2012;7(1):e29161.

Disclosure of Interests: Kristen Chen: None declared, Majid Zeidi: None declared, Nithin Reddy: None declared, Barbara White Shareholder of: Corbus Pharmaceuticals, Inc., Employee of: Corbus Pharmaceuticals, Inc., Victoria Werth: None declared

DOI: 10.1136/annrheumdis-2019-eular.7759

\section{FRI0308 HIGH LEVEL OF SERUM NEOPTERIN IS ASSOCIATED WITH RAPIDLY PROGRESSIVE INTERSTITIAL LUNG DISEASE AND REDUCED SURVIVAL IN DERMATOMYOSITIS}

Qinglin Peng, Yamei Zhang, Lin Liang, Xin Lu, Guochun Wang. China-Japan Friendship Hospital, Department of Rheumatology, Beijing, China

Background: Neopterin is primarily synthesized and released by activated macrophages/monocytes upon stimulation with interferon- $\gamma$ and is considered as a marker for macrophage activation. 